\author{
Błażej Suproń \\ West Pomeranian University of Technology in Szczecin \\ e-mail: bsupron@zut.edu.pl
}

ORCID: 0000-0002-7432-1670

\title{
INFLUENCE OF THE MOBILITY PACKAGE ON THE FUNCTIONING OF THE POLISH ROAD TRANSPORT OF GOODS SECTOR
}

WPLYW PAKIETU MOBILNOŚCI

NA FUNKCJONOWANIE POLSKIEGO SEKTORA TRANSPORTU DROGOWEGO TOWARÓW

DOI: $10.15611 / \mathrm{pn} .2020 .3 .08$

JEL Classification: R40, E24, F16

\begin{abstract}
Summary: The article presents the results of the introduction of the provisions suggested by the European Union's legislative authorities with regard to transport market regulation, referred to as the Mobility Package. The business of enterprises is based on planning, both in the short and long term, business decisions are made in advance, and internal and external factors taken into consideration. To emphasize the importance of the issues discussed, it is worth noting that the regulations under study constituted the first such in-depth change of the market since Poland joined the European Union. An earlier analysis of the solutions suggested allows enterprises to get ready for the upcoming changes and to take appropriate decisions to minimize their effects, if any. Consequently, the purpose of this paper was to attempt to assess the impact of the Mobility Package on the Polish road transport industry. To study this goal it was necessary to gather and analyse extensive research material originating from official statistical data, industry reports and scientific publications of domestic and foreign authors. The methodology of the research included analysis of the scientific literature, European Commission documents and statistical data analysis.
\end{abstract}

Keywords: road freight transport, Mobility Package, minimum wage in transport, transport market, dispatching drivers.

Streszczenie: W artykule przedstawiono potencjalne skutki wprowadzenia przepisów proponowanych przez organy ustawodawcze Unii Europejskiej w zakresie regulacji rynku transportowego określane jako Pakiet Mobilności. Działalność przedsiębiorstw powinna się opierać na planowaniu zarówno w krótkim, jak i w długim okresie. Decyzje gospodarcze przedsiębiorstwa muszą być podejmowane $\mathrm{z}$ odpowiednim wyprzedzeniem oraz $\mathrm{z}$ uwzględnieniem czynników wewnętrznych i zewnętrznych. Aby podkreślić wagę omawianej problematyki, warto zauważyć, że omawiane zmiany są pierwszą tak dogłębną zmianą na rynku od momentu akcesji Polski do Unii Europejskiej. Wcześniejsza analiza proponowanych 
rozwiązań pozwala przedsiębiorstwom przygotować się do nadchodzących zmian oraz podjąć stosowne decyzje, które umożliwią zminimalizowanie potencjalnych skutków. Celem niniejszego artykułu była próba oceny wpływu Pakietu Mobilności na polski sektor transportu drogowego. Zgromadzono i przeanalizowano bogaty materiał badawczy pochodzący $\mathrm{z}$ oficjalnych danych statystycznych, raportów branżowych oraz publikacji naukowych autorów krajowych i zagranicznych. Metodologia badań obejmuje analizę literatury naukowej, dokumentów Komisji Europejskiej oraz analizę danych statystycznych.

Słowa kluczowe: transport drogowy ładunków, Pakiet Mobilności, płaca minimalna w transporcie, rynek transportowy, delegowanie kierowców.

\section{Introduction}

The transport of commodities is of major importance in all types of business, affecting the growth of socio-economic well-being (Engström, 2016). Road transport is an industry that currently dominates in the commodities transport structure in Poland and in the whole European Union. Its share in carriage has remained stable for years, at around $72 \%$. Transport companies employ 5 million people and generate revenues of almost EUR 400 billion (Koźlak, 2018).

The development of the Polish road transport industry would have not been possible had there been no freedom to provide services, which is realised by the actions of entrepreneurs or by dispatching their employees (Czermińska, 2015). Currently, work ongoing in the European Union on the Mobility Package interferes with one of the basic pillars of the free market. Topics related to the restriction of the freedom to provide transport services, manifested by, among other things, reinforcing the application of Directive 96/71/EC concerning the dispatching of professional drivers in such member states as Germany and France, have been raised several times in scientific publications. Attention shall be paid especially to the study by Lewandowski, who examined how by means of internal regulations, some member states are trying to protect their own interests, pointing out that the regulations with regard to the minimum wage applied by the German administration have hurt in particular Polish transport companies (Lewandowski, 2016).

Liberadzki also analysed the impact of regulations related to the German minimum wage regulation (Milog) extended to the business of Polish road hauliers, emphasizing that in the long term, these solutions may have an adverse impact on the condition of road transport in the territory of the EU not only in the sphere of competitiveness, but also in the issue of the usability of the existing transport infrastructure, and that being built and planned (Liberadzki, 2015). However, Paprocki pointed out that the minimum wage regulations set out in Germany violate the basic principles of the European Union, such as the free movement of goods and services and it forces foreign transport companies to adjust their employees' wages to German conditions. This is a failure of EU transport policy (Paprocki, 2015). 
One can also find references to the planned provisions of the Mobility Package in scientific publications. According to Waśkiewicz, Menes and Gis, following the intense involvement of Polish hauliers, among other markets in Germany the Mobility Package, including also the provisions on dispatching workers in road transport, will have an impact on the unit costs of Polish companies, and thus will influence to some extent their competitiveness on the market (Waśkiewicz, Menes, and Gis, 2018). Borkowski and Bąk also undertook a preliminary analysis of the effects, if any, of the Mobility Package, pointing out that the suggested provisions with regard to road commodities transport will limit competition, finally generating an increase in the cost of transport services through regulatory changes of dispatching workers and reduction of cabotage (Borkowski and Bak, 2018). As for publications and papers drawn up at the request of the Ministry of Infrastructure and Construction, they show that the enactment of the Mobility Package will have an adverse impact on companies from peripheral EU states, in particular Poland, and will increase wage costs, which in turn will be particularly painful to small enterprises (Bąk, Borkowski, Czuba, Koźlak, and Zamojska, 2017).

Apart from the problem of drivers' wages, access to the transport market, in particular to cabotage services, remains also a contentious issue. Its impact on the transport market, along with setting out principles to satisfy Western and Central European states together with Eastern Europe, makes up the topic of scientific discussions. Following the concept suggested in 2009, cabotage was to be only a temporary form, while striving at lifting all restrictions to having access to the transport market (L 300/72). The prevailing part of the scientific community dealing with these topic, notes the positive effects of mitigating the market access regulations. Lesiak indicates that the total lifting of restrictions of access to cabotage markets would be a "pro-ecological" step, as it would reduce the share of 'empty' mileage in road transport across Europe (Lesiak, 2010). The European Commission is also of the opinion that the currently functioning solution brings positive effects, but it is insufficient as $20 \%$ to $25 \%$ of trucks in the European Union cover distances unloaded through the restrictions in force since 2009. This costs about EUR 50 million annually (EC, 2014). According E. Załoga, road cabotage has a positive impact on the transport market, however it causes dissatisfaction amongst local companies in such countries as Germany or France, which under pressure from trade unions carry out actions to protect their national markets (Załoga, 2017).

An analysis of the scientific publications on the subject of access to the cabotage transport market shows that the opinions on the regulations in force are very diverse. On the one hand, such scholars as Gis, and Waśkiewicz (2017), Ślęzak, Kordel, and Waśkiewicz (2019) and institutions such as the European Commission (EC 2017), the Polish Road Transport Institute (PITD, 2019) and the Motor Transport Institute (ITS, 2017) are of the opinion that the deregulation of the transport market was a good solution from which companies from Central and Eastern Europe, Polish included, had profits. Yet there are other researchers like Sternberg and Hofmann 
(2019), and Hilal (2008), who point out in their papers many negative consequences of this market deregulation for the transport industry, which particularly affected enterprises in Western European states.

As the discussed regulations make up a completely new manner of organizing the transport market, and there are no detailed analyses carried out with reference to this field, as well as given the discussions in the scientific and economic environment, the main goal of this paper is an attempt to assess the impact of the Mobility Package on the Polish road transport industry.

\section{Research material and methods}

The scope of the assumed research problem, the purpose of the research, as well as the application of the results obtained, if any, required the use of differentiated research methods. The documentary method, the analysis of statistical data, originating from secondary sources, the economic analysis method and the analysis of legal acts were applied in this paper. The research material consisted in statistical data from the Central Statistical Office and Eurostat, domestic and foreign scientific publications, and also the reports and expert opinions of institutions of international significance. The data obtained and ex-post results were the basis for the future considerations.

These methods were adopted because the regulations discussed are currently in the implementation phase, and therefore it is not possible to forecast the effects of changes in the form of hard evidence. Up to now, such wide-ranging changes on the transport market have never been carried out. The results obtained, although not based on model forecasts, can make up the basis for future scientific discussion and can also be used in business practice by the management of transport companies. The above considerations are also aimed at providing information to enterprises which need to make some decisions under strategic management much earlier so as to adapt better to the upcoming changes.

\section{Polish road freight transport - the current position}

The first stage of the study was to determine the position of the road transport industry in Poland so as to assess the results of the regulations suggested under the Mobility Package. The overall position of the Polish road transport industry between 2008 and 2017 was advantageous. Since 2009, i.e. when the transport market in the European Union fully opened, the domestic road hauliers successively increased their market position, rising up to the position of leader, which is noticeable in many areas of their business.

A long-term analysis of the transport market points out that since 2008 the volume of transport work carried out by Polish companies has been increasing. While in the base year it amounted to 164.9 billion tkm, in 2010 it increased to 202.3 


\begin{tabular}{|c|c|c|c|c|c|c|c|c|c|c|c|c|c|c|c|c|c|}
\hline$\stackrel{ }{\vec{\partial}}$ & $\begin{array}{l}0 \\
\dot{+} \\
\dot{m}\end{array}$ & $\begin{array}{l}\stackrel{0}{\infty} \\
\stackrel{\infty}{\sim}\end{array}$ & $\begin{array}{l}n \\
\sim \\
m \\
m\end{array}$ & $\begin{array}{c}n \\
0 \\
0\end{array}$ & $\stackrel{\varrho}{\Xi}$ & 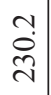 & 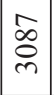 & $\begin{array}{l}0 \\
\dot{I}\end{array}$ & $\exists$ & $\underset{r}{r}$ & 它 & $\stackrel{+}{i}$ & $\begin{array}{l}0 \\
i\end{array}$ & $\begin{array}{l}0 \\
\dot{r}\end{array}$ & $\begin{array}{c}\mathscr{\sim} \\
\stackrel{\sim}{f}\end{array}$ & $\stackrel{?}{\stackrel{n}{\beth}}$ & $\vec{a}$ \\
\hline 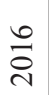 & $\vec{m}$ & 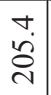 & 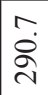 & \begin{tabular}{|l|} 
\\
$i$ \\
$i$
\end{tabular} & $\ddot{0}$ & $\overrightarrow{\vec{\sim}}$ & $\frac{\Delta}{\grave{d}}$ & $\begin{array}{l}\nu \\
\check{2} \\
\end{array}$ & $\ddot{0}$ & gे & $\begin{array}{l}\infty \\
\dot{q} \\
\dot{q}\end{array}$ & \begin{tabular}{|c|}
\multirow{2}{*}{} \\
\end{tabular} & $\begin{array}{ll} \\
\end{array}$ & \begin{tabular}{|l|} 
\\
\end{tabular} & $\begin{array}{c}\sim \\
\ddot{y} \\
\end{array}$ & $\ddot{a}$ & $\begin{array}{l}1 \\
\infty \\
\infty\end{array}$ \\
\hline$\frac{n}{\stackrel{n}{c}}$ & $\frac{n}{m}$ & $\begin{array}{l}\forall \\
\ddot{\infty} \\
\infty\end{array}$ & $\stackrel{i}{\dot{D}}$ & $\mid \begin{array}{l}\infty \\
\\
\end{array}$ & $\tilde{a}$ & $\begin{array}{l}\dot{v} \\
\stackrel{a}{a}\end{array}$ & 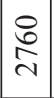 & $\hat{o}$ & \begin{tabular}{l|}
$\infty$ \\
$\infty$
\end{tabular} & $\stackrel{0}{\circ}$ & $\begin{array}{l}0 \\
\stackrel{\gamma}{\gamma}\end{array}$ & $\frac{9}{\dot{\gamma}}$ & $\stackrel{+}{-}$ & $\ddot{m}$ & $\mid \begin{array}{c}\infty \\
\infty \\
\infty \\
m\end{array}$ & $\underset{\Xi}{\Xi}$ & $\begin{array}{l}\infty \\
\hat{a}\end{array}$ \\
\hline$\stackrel{ \pm}{\stackrel{\sim}{*}}$ & $\ddot{n}$ & $\begin{array}{l}0 \\
0 \\
0 \\
0 \\
-\end{array}$ & $\begin{array}{l}\hat{0} \\
\stackrel{2}{n}\end{array}$ & $\frac{n}{6}$ & $\begin{array}{l}0 \\
\infty \\
\infty\end{array}$ & $\stackrel{m}{\beth}$ & $\begin{array}{l}\hat{\tilde{n}} \\
\sim\end{array}$ & $\hat{a}$ & 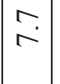 & $\begin{array}{l}0 \\
0 \\
0\end{array}$ & ?ִ & $\begin{array}{l}0 \\
\dot{m}\end{array}$ & $\because$ & $\vec{i}$ & $\overrightarrow{\stackrel{Y}{f}}$ & $\stackrel{\stackrel{N}{\Xi}}{\Xi}$ & $\begin{array}{l}0 \\
\infty \\
0\end{array}$ \\
\hline$\stackrel{m}{\stackrel{\sim}{\sim}}$ & $\underset{\sim}{\sim}$ & $\begin{array}{l}0 \\
\dot{+} \\
\stackrel{\sim}{-}\end{array}$ & 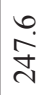 & $\begin{array}{l}n \\
2 \\
n\end{array}$ & $\stackrel{ナ}{\sim}$ & $\stackrel{?}{\stackrel{2}{2}}$ & $\hat{\circ}$ & $\dddot{\infty}$ & $\stackrel{0}{\circ}$ & is & 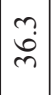 & $\begin{array}{c}n \\
n \\
n \\
m\end{array}$ & $\grave{o}$ & $\begin{array}{l}0 \\
\dot{r}\end{array}$ & $\begin{array}{c}\sim \\
\infty \\
\infty \\
m\end{array}$ & $\stackrel{+}{\stackrel{0}{\Xi}}$ & $\begin{array}{c}0 \\
\infty \\
\infty\end{array}$ \\
\hline 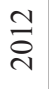 & 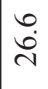 & $\stackrel{m}{ \pm}$ & 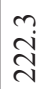 & 8 & n? & $\begin{array}{l}n \\
\tilde{\sigma} \\
- \\
\end{array}$ & 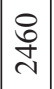 & $\underset{\infty}{\sim}$ & $\begin{array}{l}\infty \\
0 \\
0\end{array}$ & m? & $\begin{array}{l}a \\
\dot{b} \\
\text { re }\end{array}$ & $\left|\begin{array}{c}a \\
i n \\
n\end{array}\right|$ & $\ddot{0}$ & $\begin{array}{l}0 \\
i \\
i\end{array} \mid$ & $\begin{array}{l}a \\
\dot{b}\end{array}$ & $\begin{array}{l}\infty \\
\dot{\theta}\end{array}$ & วุ' \\
\hline $\overrightarrow{\vec{\sim}}$ & ثั & $\begin{array}{c}0 \\
\stackrel{\infty}{+} \\
\stackrel{+}{ \pm}\end{array}$ & ì & $\left|\begin{array}{l}\infty \\
0 \\
i \\
n\end{array}\right|$ & $\stackrel{\infty}{\infty}$ & $\begin{array}{l}n \\
\tilde{n} \\
n\end{array}$ & $\underset{\sim}{\stackrel{\sim}{\sim}}$ & $\stackrel{r}{i}$ & $\vec{r}$ & $\begin{array}{l}0 \\
i\end{array}$ & $\begin{array}{l}n \\
\dot{m} \\
\end{array}$ & $\begin{array}{l}m \\
m \\
m\end{array}$ & $\stackrel{0}{-}$ & $\begin{array}{l}0 \\
\dot{r}\end{array}$ & $\begin{array}{l}+ \\
\dot{m}\end{array}$ & $\frac{n}{0}$ & $\frac{m}{a}$ \\
\hline$\stackrel{\circ}{\stackrel{\sim}{\sim}}$ & $\stackrel{\leftrightarrow}{\dot{J}}$ & $\frac{n}{n}$ & ๙ై & 苛 & के & $\begin{array}{l}\infty \\
\dot{\sim} \\
\stackrel{+}{\mid}\end{array}$ & $\begin{array}{l}\infty \\
\stackrel{\infty}{\sim} \\
\underset{1}{n}\end{array}$ & \begin{tabular}{|l|}
$\infty$ \\
0 \\
0
\end{tabular} & ?ִ & $\dot{m}$ & ڤे. & $\vec{i}$ & $\stackrel{0}{-}$ & $\ddot{n}$ & $\begin{array}{l}\sim \\
\stackrel{f}{n}\end{array}$ & Nִ & $\vec{\infty}$ \\
\hline ஓे & $\dot{\vec{\nu}}$ & 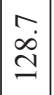 & $\begin{array}{l}\ddot{0} \\
\stackrel{\infty}{0}\end{array}$ & 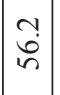 & $\begin{array}{l}0 \\
\stackrel{i}{i}\end{array}$ & $\begin{array}{l}n \\
0 \\
n \\
n\end{array}$ & $\overrightarrow{\widetilde{\sim}}$ & $\begin{array}{l}\infty \\
i \\
i\end{array}$ & $\begin{array}{l}n \\
n\end{array}$ & $m$ & $\begin{array}{l}0 \\
0 \\
\dot{0}\end{array} \mid$ & $\begin{array}{l}0 \\
\dot{0} \\
\sim\end{array}$ & $\stackrel{+}{0}$ & $\begin{array}{l}\tilde{N} \\
\end{array}$ & $\vec{m}$ & $\ddot{\theta}$ & $\begin{array}{c}\hat{\infty} \\
\dot{\alpha}\end{array}$ \\
\hline $\begin{array}{l}\infty \\
\stackrel{\sim}{\circ} \\
\end{array}$ & ?̊ & $\begin{array}{l}\infty \\
\dot{0} \\
\stackrel{\sim}{c}\end{array}$ & $\begin{array}{l}9 \\
\dot{+} \\
\stackrel{-}{-} \\
\end{array}$ & $\mid \begin{array}{l}+ \\
\dot{0} \\
\sim\end{array}$ & $\hat{\sigma}$ & $\vec{a}$ & $\frac{m}{\vec{n}}$ & $\overrightarrow{i n}$ & is & $\stackrel{n}{n}$ & $\begin{array}{l}n \\
0 \\
2\end{array}$ & 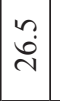 & $\overrightarrow{0}$ & $\overrightarrow{0}$ & $\frac{a}{m}$ & $\underset{-}{-}$ & $\stackrel{1}{0}$ \\
\hline 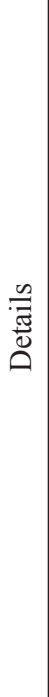 & 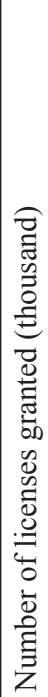 & 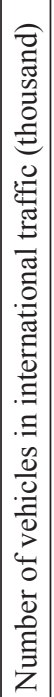 & 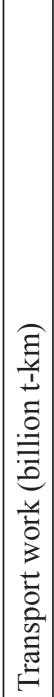 & 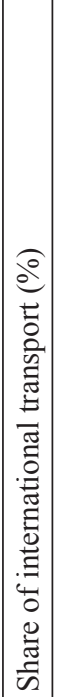 & 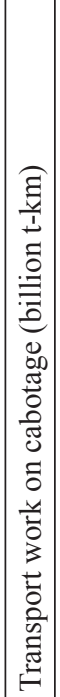 & 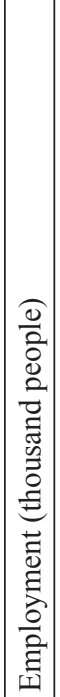 & 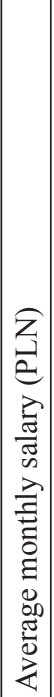 & 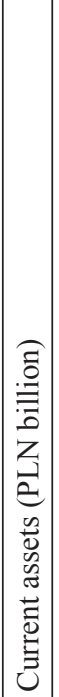 & 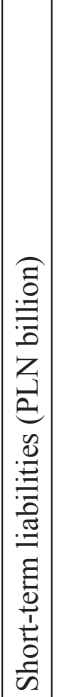 & 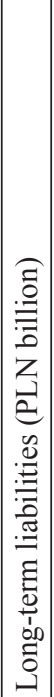 & 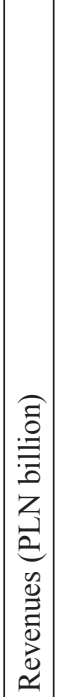 & 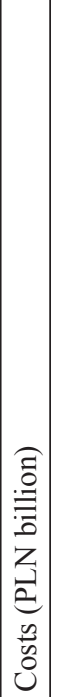 & 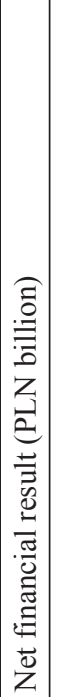 & 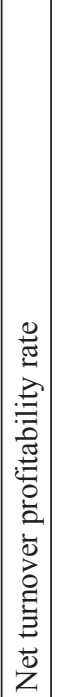 & 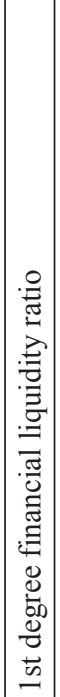 & 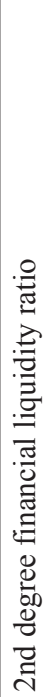 & 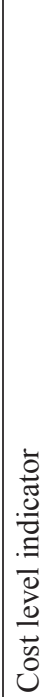 \\
\hline
\end{tabular}


billion tkm. The next years were characterized by further growth and in 2017, transport performance amounted to 335.2 billion tkm (see Table 1). This means that between 2008 and 2017, transport performance achieved by Polish road hauliers increased by $49.1 \%$, which is the highest increment among all the European Community states. At the same time, the share of Polish enterprises in the analysed period in commodities transport grew from $10.6 \%$ to $17.4 \%$, which placed Poland in first place in the European Union.

The mass of transported loads also increased, as in 2009 it amounted to 1.17 billion tonnes, and in 2017 to 1.39 billion tonnes. In this respect, Polish road hauliers took third place amongst all the European Union states, with a share of $10.2 \%$. The vast majority of transport services $(63.3 \%)$ were those of international transport, and between 2008 and 2017, the value of this share increased by 6.9\% (in 2008, international transport accounted for $56.4 \%$ of all transport services).

The scale of development of the transport industry in Poland is also depicted by the increase in the number of road hauliers. In 2008 there were 20,481 enterprises licensed in international cargo transportation, while in 2017 their number increased to 34,633 (a $69.1 \%$ rise). The number of vehicles used increased by $71.9 \%$ (from 126 785 in 2009 to 217984 in 2018). In terms of the number of enterprises with a Community license in the European Union, Poland was in the second place in 2018. The fleet used by Polish transport companies was one of the most modern amongst hauliers from all EU states (19.2\% of vehicles used in 2017 were less than three years old).

Road transport also generated significant economic earnings. In 2017 the value of exported transport services amounted to EUR 737.8 billion (this made up $16.3 \%$ of the value of all Polish services exported). The most important recipients of Polish transport services were such Germany (31.4\%), the Netherlands (12.3\%) and France (9.1\%). Polish companies specialized first of all in cabotage transport services. In 2017, Polish road hauliers carried out $40.1 \%$ of all transport operations of this type that were provided in the European Union, with transport performance at the level of 11.9 billion tkm (transport performance increased by 9.3 billion tkm compared to 2009).

Statistical data on the Polish road transport industry clearly indicate that in the past decade, Polish companies dominated the European Union market, and the Polish economy specialized in transport services, generating almost 5.6\% of GDP in 2017. The increase in the number of transport services was observed in all Polish regions, bringing about, among other things, a reduction in unemployment and the development of other industries related to the services provided to transport entities such as forwarding services, repair and trade in heavy-load vehicles, and training of professional drivers.

In 2017, transport companies generated revenues from the sale of transport services at the level of PLN 54.7 billion. These revenues were burdened with costs of PLN 52.4 billion. An analysis of the cost structure indicates that external services 
(43.3\%), salaries (20.5\%) and the consumption of materials and energy (19.2\%) had the largest share.

A detailed analysis of the financial position of Polish hauliers indicates that the industry faced serious problems between 2007 and 2017. In 2017 the net turnover return rate was $3.6 \%$, the financial liquidity ratio I was $42.5 \%$, the financial liquidity ratio II was $121.3 \%$, and the cost level ratio was $99.1 \%$. Between the years 2008 and 2017 , the above ratios deteriorated. The transport industry was also gaining a growing value of liabilities. In 2017, short-term liabilities amounted to PLN 11.1 billion, while long-term ones were PLN 7.1 billion. Liabilities tended to increase in the analysed period.

The analysis of financial data between 2008 and 2017 indicates that, despite the expansion of Polish transport companies, the financial position of the industry was not satisfactory. The low value of the liquidity ratio I and growing liabilities indicated significant financing of enterprises' assets with the use of external resources such as leasing or rent, which also contributed to a high share of contracted services of other companies in costs, and the companies reported low returns and a heavy burden of increasing costs.

\section{The scope of the proposed regulation and its impact on individual aspects of the operation of transport companies}

The next stage of the research was to analyse the consequences of the Mobility Package being implemented, for the business of Polish road hauliers. An analysis of the following source documents: the approved position of the Committee on Transport and Tourism (TRAN) operating in the European Parliament, the agreement reached during the talks between the European Commission, the Council of the EU and the European Parliament, and approved by the Committee of Permanent Representatives of EU Member States operating within the structures of the Council of the European Union (COREPER) and voted by the European Parliament, underline that the following regulations will be the most significant for Polish road hauliers:

- imposing the application of the Posting of Workers Directive (2018/957/EU) provisions on employees carrying out cabotage, cross-trade and combined operations,

- limiting cabotage operations, by introducing cooling off period -i.e. the period in which the haulier will not be able to carry out cabotage operations within a given country (the freezing period will be 4 days),

- the obligation for the vehicle to return to the country in which the company is based once every 8 weeks and for the driver once every 4 weeks,

- the need to replace recording devices with second generation smart tachographs. Imposing the application of the Dispatching of Workers Directive' provisions on employees, carrying out cabotage and cross-trade, will cause that employers will be required to pay the employee wages at the level applied in the state in which the 
transport operations are to be carried out. At the same time, foreign labour laws will have to be applied by transport companies. The application of this regulation may have far-reaching consequences, in particular for Polish transport companies that are the European leader in cabotage transport. This results both from differences in the field of the legal provisions, social security and pay rates in the states that are the main recipients of Polish transport services. In addition, in the case of some European Union states, professional drivers have earnings based on collective labour agreements, and therefore the minimum wages depend on many complex factors.

The disproportion shown above is also associated with the lower rate of wage growth in Poland, which will result in a sudden increase in the wage costs of transport employers. Between the years 2008 and 2017, the average wages in the road transport industry in Poland increased by $45.9 \%$ (from PLN 2,313.17 gross in 2008 to PLN $3,087.19$ gross in 2017), and the average annual rise was maintained at 3.6\%. According to the Polish Central Statistical Office (GUS) data, wages made up onefifth of transport enterprises' costs on average. Kordel and Waśkiewicz (2018), also confirm these observations in their papers when they indicate that in 2016, wages and benefits of drivers accounted for $24.6 \%$ of the cost of covering $1 \mathrm{~km}$. Rolbiecki and Książkiewicz (2018) also pointed ourt $21 \%$ of the wages share in the costs of road hauliers. In turn, PWC estimates the cost of drivers' work in Polish transport companies at nearly $35 \%$ of all the costs of road transport operators (PWC, 2019).

However, it needs to be stressed that the data provided cannot be considered sufficient to assess the position, because a significant number of drivers in Poland receive reimbursement of business travel expenses, in addition to wages, and that cost is not included in personal earnings. Thus, it is difficult to estimate the actual amount of drivers' wages and their share in the costs. Currently no objective analytical paper is available that would reliably determine in a precise manner the amount of the average salary, all cash benefits paid taken into account. However, pointing to one of the few studies, i.e. the Transjobs firm's report (2018), the real amount of wages paid to drivers employed in companies dealing in the international road transport of goods fluctuated around the level of PLN 4,300 net (small companies) to PLN 6,459 net in medium-sized enterprises (mediana: PLN 5,218). The report also shows that the wages on which companies pay social security contributions, and income tax for more than half of drivers was not higher than PLN 3,000, so it made up on average not more than $40 \%$ of the wages paid. In addition, it results from an analysis of statistical data that larger companies offer a larger proportion of the payout that is covered by social security. The smaller the company, the more its ability to finance additional labour costs decreases, which results in a higher share of non-taxed payout components. The research by Supron (2018) provides similar observations.

If introduced, the solutions suggested by the Mobility Package to dispatch professional drivers could cause significant changes in the manner professional drivers are paid. The West European states were the biggest recipients of Polish 
transport services. In 2019, in the three largest recipients of Polish transport services, the minimum wages were on average double the average wages in the Polish transport industry (EUR 1500 in Germany and France and EUR 1594 in the Netherlands). To adjust to the indicated regulations, Polish entrepreneurs would need not only to increase the outlay on the wages of the drivers they employ, but also to bear higher charges for their national security contributions.

The solutions suggested may mostly affect hauliers who pay the drivers they employ a larger part of wages in the form of reimbursement of business travel expenses. In this case, after the mobility package enters into force, they will have to incur more outlays - by about two thirds - to guarantee the hitherto level of their drivers' wages. This is due to the fact that currently travel benefits are paid in full without deductions provided for wages. However, if it is necessary to guarantee wages on the terms in force in other states and the amount of the so-called tax wedge is taken into account, not only will the gross wages increase, but so will the public and legal charges paid by employers. In addition, companies will have to bear the additional administrative costs with regard to dispatching process, legal services and settling wages based on foreign regulations.

Therefore, the increase in costs caused by applying the Dispatching Directive to drivers can be dangerous for the entire industry. This results from the significant cost charge, debiting the revenue of the industry. In 2017, costs accounted for $99.1 \%$ of revenue, and transport companies in Poland generated a slight surplus of profit, as shown by the low value of the turnover return ratio (in 2017 it amounted to $3.6 \%$ ). At the same time, it is clear from the analysis of the long-term trend that both the share of costs and the liquidity of Polish transport companies did not significantly improve over the period from 2008 to 2017. In addition, in the years indicated, costs and liabilities rose significantly faster than revenues. In the analysed period, the average annual increase in costs was $8.5 \%$ compared to the average annual increase in revenues, which was at the level of $7.6 \%$. The above observations show that despite the increase in the costs of services provided, the transport rates offered to road hauliers did not increase at a rate which could compensate the increase in costs incurred.

The costs incurred by transport companies depend also on macroeconomic factors such as fuel prices, currency exchange rates, road toll rates and interest rates, affecting interest on vehicle leasing. Another important fact is that the majority of Polish companies' rolling stock was financed by external sources. As revealed by the Polish Leasing Association, over $54.6 \%$ of transport companies take advantage of leasing as the primary source of financing operational business (ZPL, 2018).

The transport market is characterized by the significant fragmentation and dominance of small entities (nearly $95 \%$ of transport companies in the European Union are micro entities), and thus even in the case of increased costs of carriage services, it has an insignificant ability to adjust its transport rates (EC, 2018). The reason for this phenomenon may be explained by the event in 2019 when roads' toll 
rates increased in Germany on average by $33 \%$, but freight rates increased only by 14\% (Tim Consult, 2019). If a similar trend is kept in the case of the Mobility Package being introduced, this could cause significant difficulties with the financial liquidity of the Polish road transport industry.

Another fundamental change to be introduced under the Mobility Package is the adjustment of provisions with regard to the access to the market, in particular in the field of cabotage carriage, which is the domain of Polish hauliers. The regulations being drawn up introduce two highly significant restrictions in this area. The coolingoff period mechanism is one of them, i.e. the time in which the haulier will not have the right to carry out cabotage carriage after the time limit is over, and the other is the need for the vehicle to return once every eight weeks to the country in which the haulier is established.

The cabotage operations market is extremely important for the Polish industry. The opening of the internal market in 2009 has significantly reduced the so-called empty mileage as shown by the analysis of statistical data. Between the years 2009 and 2017, the volume of such empty mileage dropped by 5.5\% (Główny Urząd Statystyczny [GUS]. 2018). However, some researchers do not share the view on the benefits coming from deregulation. According to Sternberg and Hofmann (2018), there is no connection between empty mileage and the deregulation of 2009. The scientists conclude in their paper that cabotage operations represent only a relatively small share (about $4 \%$ ) of the whole market. Changes in the access to market will not have a negative impact on the entire industry, and could even improve the position of domestic enterprises by limiting competition.

Hendrickx (2013) is also of the opinion that the solution currently functioning in the European Union is satisfactory, and a further liberalization of rules for cabotage operations will not bring any advantages, further reduction of empty mileages included. In line with the theses presented in that paper, the current " 3 per 7 " model is an ideal compromise between competitiveness and limiting the number of empty mileage. Sternberg, Germann, and Klaas-Wissing (2013) indicate also that the currently functioning solution brings about a disruption of the cabotage operations market due to the activity of enterprises from Central and Eastern Europe, which through lower labour costs reduce the financial motivation of companies, and ordering transport, to reduce the number of empty mileage, and cabotage operations even expand the number of trucks remaining unladen while on road.

Additionally, the analysis of data on the growth in the number of enterprises and the volume of commodities transport work carried out within cabotage and international traffic, shows that the deregulation introduced in 2009 in the European Union was the main factor in the Polish transport industry development. The introduction of the Mobility Package will negatively affect the business of Polish companies which are the main beneficiary of the opening up of the market. As indicated by the Polish Road Transport Institute (PITD, 2019), the need to look for additional loads to avoid the enforced standstill of the vehicle for four days, may 
contribute to an increase in spending on fuel and road tolls. The Institute estimates that the introduction of the suggested regulations will result in the necessity for Polish transport companies to make use of an additional 200,000 tonnes of fuel per year. Furthermore, the suggested restrictions will also affect the return of transport companies, which will be forced to bear the costs of vehicle downtime, after it has used its cabotage limit.

It also has to be noted that the observance of these provisions requires the use of new recording devices, which should be introduced in all vehicles by the time the Mobility Package provisions become applicable. These devices have not been developed yet and their precise cost is unknown. On the basis of the prices of smart tachographs, it is estimated that their cost will be around PLN 0.5 billion. Replacement of tachographs with those that would tighten the control of cabotage operations is caused primarily by the problem of dishonest actions committed by road hauliers. According to Cheu, Poliak, Tomicová, and Gnap (2019), a common practice while carrying out cabotage operations is the so-called neutralization of documents, which consists in concealing the number of transport operations carried out, thus creating the chance to exceed the allowed limits. Currently, the control services have limited rights to verify the actual number of shipments transported, when they review it on the basis of paper documentation.

\section{The effects of the introduced regulations in the short and long term}

The analysis carried out indicates that the short-term economic effects of the suggested regulations will be:

- a drop in revenues, following the reduction in the number of cabotage operations,

- a disruption of competition on internal markets,

- an increase in the volume of empty mileage,

- an increase in costs caused by the need to have vehicles' downtime,

- a change in the rules of carriage organization and planning,

- an increase in payroll costs, caused by the necessity to ensure provision of drivers wages at the level, and on the principles in force in the country where the haulage is carried out,

- an increase in costs, caused by the necessity to draw up relevant documentation, legal services and adjusting settlement systems to regulations in force in other states,

- a drop in the competitive advantage of hauliers from states with lower labour costs (mainly Central and Eastern Europe),

- an increase in outlays on the purchase and replacement of recording devices,

- an increase in costs caused by the necessity to update computer and service systems along with those related to technical staff training. 
The market factors such as demand for transport services and their supply will also have an impact on the range of the effects involved by the suggested regulations. In the last decade, the share of road transport in commodities carriage in the European Union steadily increased and despite slight fluctuations remained significant (Nowakowska-Grunta and Strzelczyk, 2019). Future forecasts are also optimistic. Rossa (2016) predicts that by 2030, the demand for international transport will continue to grow. Its share in the structure of commodities transported will also increase from $14.0 \%$ to $18.4 \%$. Dorosiewicz and Waśkiewicz (2018) also confirm this tendency and in their forecast assume that by 2030 the performance of international truck transport will increase and will show an increase by $74 \%$, compared to that in 2016, i.e. from 181.4 billion tkm to 320 billion tkm in 2030 . Menes (2018) in his study also indicates that in the period between 2020 and 2030, the demand for road transport in the European Union will be characterized by an increase (increase forecast by 336 billion tkm).

Therefore, based on the presented ex-post data and industry forecasts, two development scenarios for the Polish transport industry can be assumed:

- An increase in rates caused by a drop in the supply of transport services, as a result of growing operational costs of transport companies with a growing demand for transport services. In this scenario, most of the existing enterprises will keep operating on the market, and the long-term position in the industry will depend on their profits. At the same time, the rising transport costs will cause an increase in product prices.

- Maintaining freight rates at the current level or a position in which after the introduction of the Mobility Package freight rates do not achieve a similar increase as the costs associated with its implementation in transport enterprises. In such a case, in a short period of time many enterprises may turn out to be unprofitable, and in the long term they could vanish from the market. Assuming the occurrence of this scenario in the long term because of the drop in supply in the industry, there would be an adjustment of prices on the market and an increase in transport rates with the assumption that the demand for road transport services will grow or remain at the current level.

It should also be noted that in both scenarios, an increase in transport prices is assumed, which may occur in various economic periods, depending on the market response to introduced regulations and the demand for road transport, which in turn depends on complex macroeconomic factors such as growth of GDP, investment and industrial production.

As indicated by the report prepared by PWC (2019), in the perspective of two to five years from the introduction of the Mobility Package there is a high probability of an increase in operating costs, a decrease in revenues and the risk that a large number of small enterprises will leave the market. At the same time, large enterprises with the necessary financial resources may consolidate. Therefore, the occurrence of the first scenario may mean a significant reduction in the number of small transport 
enterprises. In the long run, the industry may go through a concentration, by creating large international groups that will be in a position to create more efficient logistic networks with greater bargaining power at EU level. The opinion on the results of the suggested changes is also shared by Borkowski and Bak (2018) who point out that these regulations will reduce competition in the industry and may have an unequal impact on small and large transport companies, as well as on companies from Central and Eastern Europe compared to Western ones.

\section{Conclusion}

The introduction of the Mobility Package provisions to the extent suggested by the legislative bodies of the European Union will have a significant impact on the transformation of the European transport market. A study of the development of Polish transport companies points out that in the last decade, road hauliers from Poland took perfect advantage of the position, instigated by the deregulation of the market after 2009, achieving the dominant position. Competitive advantage was possible due to lower labour and social security costs, which encouraged companies ordering transport to avail themselves of the services of Polish companies. It also brought about a reduction in freight rates. This also caused transport companies from such states as France, Germany and the Netherlands to experience difficulties in competing with their Polish counterparts.

The decade to come will be much more difficult for Polish road hauliers. The introduction of the Mobility Package, apart from the administrative charges, will have far-reaching effects related to the reorganization of the entire market. The analysis of the presented data shows that even a small growth in the costs of conducted operations may lead to the insolvency of many enterprises, which in recent years have operated at break-even point, characterized by the high level of debt in connection with investments.

The considerations presented in the paper are clearly theoretical, because the exact effects of the regulation can be estimated only a few years after its introduction. However, both the presented results and expert studies clearly suggest that the drastic market regulation will bring about as its effect an increase in prices on the transport market caused by rising costs of enterprises and a reduced supply linked to the withdrawal from the industry of some unsustainable entities. The competitive market of today may also risk concentration, which would contribute to a growth in freight rates. The final effect of the regulation will certainly bring about an increase in the prices of final goods, as following the higher transport costs, enterprises will increase the prices of their commodities.

The undoubted transformations of the transport market need to be the subject of further discussion of both scholars and industry practitioners, and the assumptions provided in this paper may serve as a contribution to further research in this field. 


\section{References}

Bąk, M., Borkowski, P., Czuba, T., Koźlak, A., and Zamojska, A. (2017). Wpływ rewizji przepisów UE w zakresie międzynarodowego transportu drogowego na przedsiębiorstwa transportowe w Polsce. Warszawa: Ministerstwo Infrastruktury i Budownictwa.

Borkowski, P., and Bąk, M. (2018). Short and long-term consequences of further regulation of the European Union Road Haulage Market. Journal of Management and Financial Sciences, (11), 9-23.

Cheu, K., Poliak, M., Tomicová, J., and Gnap, J. (2019). Neutralization of CMR documents. Archiwum Motoryzacji, (1), 175-184.

Czermińska, M. (2015). Rynek usług bez barier w Unii Europejskiej - działania na rzecz jego realizacji. Unia Europejska, (4), 21-29.

Dorosiewicz, S., and Waśkiewicz, J. (2018). Projekcja rozwoju rynku międzynarodowego transportu ciężarowego w Polsce do 2030 r. Transport Samochodowy, (2), 5-13.

EC (2014). Sprawozdanie Komisji dla Parlamentu Europejskiego i Rady w sprawie stanu unijnego rynku transportu drogowego. Retrieved 20.01.2020 from https://eur-lex.europa.eu/legal-content/ $\mathrm{PL} / \mathrm{TXT} / \mathrm{PDF} /$ ?uri=CELEX:52014DC0222\& from $=\mathrm{PL}$

EC (2017). An overview of the EU road transport market in 2015. Retrieved 20.01.2020 from https:// ec.europa.eu/transport/modes/road/studies/road_en

EC (2018). EU transport figures. Statistical pocketbook 2018, Retrieved 20.01.2020 from

https://ec.europa.eu/transport/facts-fundings/statistics/pocketbook-2018_en

Engström, R. (2016). The roads' role in the freight transport system. Transportation Research Procedia, (14), 1443-1452. DOI: 10.1016/j.trpro.2016.05.217

Gis, W., and Waśkiewicz, J. (2017). Development of the international freight transport sector in Poland against the background of the EU market. Combustion Engines, (4), 181-184.

Główny Urząd Statystyczny [GUS]. (2018). Transport - wyniki działalności w 2017 r. Retrieved 20.02.2020 from https://stat.gov.pl/files/gfx/portalinformacyjny/pl/defaultaktualnosci/5511/9/ 17/1/transport_wyniki_dzialalnosci_w_2017.pdf

Hendrickx, F. (2013). The impact of untightening of cabotage: executive summary. Retrieved 20.01.2020 from http://transportweb.dk/downloads/files/cabotage_Holland.pdf

Hilal, N. (2008). Unintended effects of deregulation in the European Union: the case of road freight transport. Sociologie du Travail, (50), 19-29.

ITS (2017). The impact of regulation of the road transport sector on entrepreneurship and economic growth in the European Union. Retrieved 20.01.2020 from https://www.mobilelabour.eu/wp-content/uploads/2018/02/The-Impact-of-Regulation-of-the-Road-Transport-Sector-on-Entreperneurship-and-Economic-Growth.pdf

Kordel, Z., and Waśkiewicz, J. (2018). Characteristics of Polish international freight transport. Research Journal of the University of Gdańsk, (80), 109-118.

Koźlak, A. (2018). Struktura sektora transportu drogowego w Polsce i ocena jego wyników ekonomicznych na tle państw Unii Europejskiej. Studia i Prace Kolegium Zarzqdzania i Finansów SGH, (166), 59-75.

Lesiak, P. (2010). Wpływ koncepcji zrównoważonego rozwoju na konkurencyjność polskich przedsiębiorstw transportowych. Transport Samochodowy, (1), 33-42.

Lewandowski, P. (2016). Protekcjonizm państwowy w przewozach drogowych. Autobusy: Technika, Eksploatacja, Systemy Transportowe, (12), 1814-1817.

Liberadzki, B. (2015). Konkurencja i kooperacja w europejskim transporcie samochodowym a niemiecka ustawa Milog. Problemy Transportu i Logistyki, (29), 147-179.

Menes, M. (2018). Syntetyczny przegląd unijnych i narodowych prognoz przewozowych ze szczególnym uwzględnieniem samochodowego transportu ciężarowego w perspektywie roku $2030 \mathrm{i}$ dalszej. Transport Samochodowy, (1), 25-35. 
Nowakowska-Grunta, J., and Strzelczyk, M. (2019). The current situation and the directions of changes in road freight transport in the European Union. Transportation Research Procedia, (39), 350-359.

Paprocki, W. (2015). EU transport policy failure: the case of Germany's Mindestlohngesetz. In M. Bąk (Ed.), Transport Development Challenges in the Twenty-First Century. Proceedings of the 2015 TranSopot Conference, Springer, 51-65.

PITD (2019). Transport i logistyka jako strategiczna branża dla polskiej gospodarki. Retrieved 20.01.2020 from https://pitd.org.pl/2019/10/03/raport-transport-i-logistyka-jako-strategiczne-dlapolskiej-gospodarki/

PWC (2019). Transport przyszłości - perspektywy rozwoju transportu drogowego w Polsce 20202030. Retrieved 20.02.2020 from https://www.pwc.pl/pl/publikacje/2019/transport-przyszlosci-perspektywy-rozwoju-transportu-drogowego-w-polsce-2020-2030.html

Rolbiecki, R., and Książkiewicz, D., Performance of Polish road carriers in relation to regulations according to the remuneration of seconded workers. Research Journal of the University of Gdańsk, (77), 115-124.

Rossa, G. (2016). Rozwój konkurencji na rynku usług transportowych - uwarunkowania i kierunki. Marketing i Zarzadzanie, (1), 173-187.

Rozporządzenie Parlamentu Europejskiego i Rady (WE) nr 1072/2009 z dnia 21 października 2009 r. dotyczące wspólnych zasad dostępu do rynku międzynarodowych przewozów drogowych (L $300 / 72)$.

Supron, B. (2018). Analysis of cost structure of international road transport operators in the West Pomeranian voivodeship in the years 2008-2014. The Central European Review of Economics and Management, (2), 61-86.

Sternberg, H., Germann, T., and Klaas-Wissing, T. (2013). Who controls the fleet? Initial insights into road freight transport planning and control from an industrial network perspective. International Journal of Logistics: Research and Applications, (16), 493-505.

Sternberg, H., and Hofman, E. (2018), Deregulation: the case of cabotage in Germany. International Symposium of Logistics. Retrieved 20.01.2020 from https://www.researchgate.net/profile/Shuya Zhong/publication/331332727_Operational_framework_for_healthcare_supplier_selection_under_a_fuzzy_multi-criteria_environment/links/5c746c1fa6fdcc $47159 \mathrm{bf} 1 \mathrm{ef} /$ Operational-framework-for-healthcare-supplier-selection-under-a-fuzzy-multi-criteria-environment.pdf\#page $=340$

Ślęzak, M., Kordel, Z., and Waśkiewicz, J. (2019). Problemy funkcjonowania polskiego transportu drogowego w przewozach ładunków. Studia i Prace Kolegium Zarzqdzania i Finansów SGH, (172), 89-99.

Tim Consult (2019). Transport Market Monitor Nov. 2019. Retrieved 20.01.2020 from http://www. perseus-web.fr\%2Fnar6\%2Fuploads\%2Ftmm35-en.pdf\&usg=AOvVaw3k96voquqB0MEE16ofKfGd

Transjobs (2018). Zarobki kierowców zawodowych w Polsce. Retrieved 20.01.2020 from https://www. transjobs.eu/Raport-TransJobs.eu-Zarobki-kierowcow-zawodowych-2018.pdf

Waśkiewicz, J., Menes, M., and Gis, W. (2018). Eksperckie oszacowanie skali zaangażowania krajowych przedsiębiorstw międzynarodowego transportu ciężarowego w przewozach na obszarze Niemiec. Transport Samochodowy, (1), 7-23.

Załoga, E. (2017). Kabotaż drogowy a reguły rynku wewnętrznego Unii Europejskiej. Zeszyty Naukowe Uniwersytetu Gdańskiego. Ekonomika Transportu i Logistyka, (64), 201-211.

ZPL (2018). Wyniki branży leasingowej za 2018 r. Retrieved 20.01.2020 from http://leasing.org.pl/ statystyki/2018 